\title{
Properties of Anatase Films for Photocatalyst from Peroxotitanic Acid Solution and Peroxo-Modified Anatase Sol
}

\author{
Hiromichi ICHINOSE, Akihiko KAWAHARA and Hiroaki KATSUKI \\ Saga Ceramics Research Laboratory, 3037-7, Arita-machi, Nishimatsuura-gun, Saga 844 \\ ペルオキソチタン酸溶液及びペルオキソ改質アナターゼゾルから作製した \\ 光触媒用アナターゼ膜の特性 \\ 一ノ瀬弘道・川原昭彦・勝木宏昭 \\ 佐賀県蜜業技術センター, 844 佐賀県西松浦郡有田町 3037-7
}

\begin{abstract}
Anatase films for a photocatalyst have been prepared on substrates by a dip-coating technique using peroxotitanic acid (PTA) solution and peroxo-modified anatase (PA) sol. The as-dried film prepared from PA sol had already crystallized to anatase phase, while the film prepared from PTA solution crystallized above $300^{\circ} \mathrm{C}$. Adhesion strength of the films at $300^{\circ} \mathrm{C}$ was over $60 \mathrm{MPa}$, and their relative density was over $80 \%$. Photocatalytic efficiency of the film prepared from PA sol for the degradation of acetic acid was higher than that of the film prepared from PTA solution. The films obtained above $300^{\circ} \mathrm{C}$ from PA sol exhibited the highest catalytic activity. However, the film less than $0.70 \mu \mathrm{m}$ thick resulted in decrease of photocatalysis.
\end{abstract}

[Received May 13, 1996; Accepted July 17, 1996]

Key-words : Anatase, Film, Peroxotitanic acid solution, Peroxo-modified anatase sol, Density, Adhesion, Photocatalysis

\section{Introduction}

Anatase film has attracted much attention as a photocatalyst for the decomposition of organic compounds. ${ }^{1)-5)}$ The anatase film has been prepared by various methods. Dip-coating of anatase sol prepared by the sol-gel method is very useful in the preparation of films onto wide-area bodies at low temperatures. ${ }^{6), 7)}$ However, the sol-gel method has several practical disadvantages. For example, organometallic compounds are expensive, and are intractable because of thier hydrolysis with water in air. Also, the anatase sol prepared by this method is unstable and acidic. Furthermore, the treatment temperature to obtain the anatase film is relatively high.6)-9)

Recently, we reported on the preparation and properties of peroxotitanic acid (PTA) solution and peroxo-modified anatase (PA) sol. ${ }^{10)}$ The PTA solution and the PA sol have many merits compared with sol-gel-derived anatase sol. In particular, they can be coated onto various materials such as metal because they have neutral $\mathrm{pH}$. They can be easily prepared, and are stable for long periods. Therefore, the cost performance and handling are better than those of the sol-gel-derived sol. In addition, dense anatase film is expected to be obtained at a lower temperature than in the case of using conventional coating agents, because they are almost free of impurities and crystallize to the anatase phase at low temperatures. Thus, the PTA solution and the PA sol are promising as raw materials for the anatase film preparation.

In the present study, the anatase film was prepared from the PTA solution and the PA sol by dip-coating, for use as a photocatalyst. In order to estimate the practical properties of the film, film density and adhesion to the substrate were examined. The difference in the photocatalytic efficiency of the films on the degradation of acetic acid was also discussed.

\section{Experimental}

PTA solution $\left(0.2 \mathrm{~mol} / \mathrm{dm}^{3}\right)$ and PA sol $\left(0.2 \mathrm{~mol} / \mathrm{dm}^{3}\right)$ were used as dip-coating agents. Their preparation process has been reported previously. ${ }^{10)}$ Films were obtained by dipping borosilicate glass substrates in the coating agents and subsequently pulling them up at a constant speed $(0.5 \mathrm{~cm}$. $\left.\min ^{-1}\right)$. After each coating, the films were dried at $50^{\circ} \mathrm{C}$ for $10 \mathrm{~min}$. This procedure was repeated 1-4 times. Finally, the as-dried films were heated at a temperature from $50^{\circ} \mathrm{C}$ to $600^{\circ} \mathrm{C}$ for $1 \mathrm{~h}$.

Film thickness was determined by scanning electron microscope (SEM) observation. The surface and cross-sectional morphology of the film were observed by SEM. The crystal phase in the films was identified by X-ray diffractometry (XRD). Relative density of the film was calculated using

$$
n_{\mathrm{f}}=p \cdot n_{\mathrm{b}}+(1-p) n_{\mathrm{v}}
$$

where $p$ is relative density, $n_{\mathrm{f}}, n_{\mathrm{b}}$ and $n_{\mathrm{v}}$ are refractive indices of the anatase film, anatase bulk $(2.554$ at $589 \mathrm{~nm}$ of wavelength) and vacancy (1.33), respectively. ${ }^{11}$ ) The refractive index $n_{\mathrm{f}}$ was determined by conventional interference analysis. ${ }^{11)}$

Adhesion of the film to the substrate was evaluated by a tensile strength test using an aluminum stud of $0.269 \mathrm{~mm}$ in diameter mounted perpendicularly to the film surface with a thermosetting resin at $150^{\circ} \mathrm{C}$ for $90 \mathrm{~min} .{ }^{12)}$ The film obtained at below $150^{\circ} \mathrm{C}$ was joined with a stud at room temperature using another adhesive. Pulling rate in the tensile test was $1 \mathrm{~kg} / \mathrm{s}$. After the test, the fractured surface was observed by SEM to ascertain whether or not the film had peeled off from the substrate.

Photocatalytic activity of the film $(10 \times 40 \mathrm{~mm})$ was evaluated in acetic acid solution $\left(1 \mathrm{~mol} / \mathrm{m}^{3}, 4 \mathrm{~cm}^{3}\right)$ in a silica glass cell. The solution was bubbled with oxygen gas during irradiation. A black fluorescent lamp ( $6 \mathrm{~W})$ was used as a light source. The strength of irradiation was $1.9 \mathrm{~mW} / \mathrm{cm}^{2}$ in the range of wavelength from 320 to $380 \mathrm{~nm}$. The concentration of acetic acid was determined by gas chromatography.

\section{Results and discussion}

3.1 Microstructure and density

The as-dried films were light yellow in color due to the undecomposed peroxo group, while the films heated at above $300^{\circ} \mathrm{C}$ were transparent but showed coloration due to interference of light. Figure 1 shows typical XRD profiles of the films prepared from PTA solution and PA sol. The films ob- 


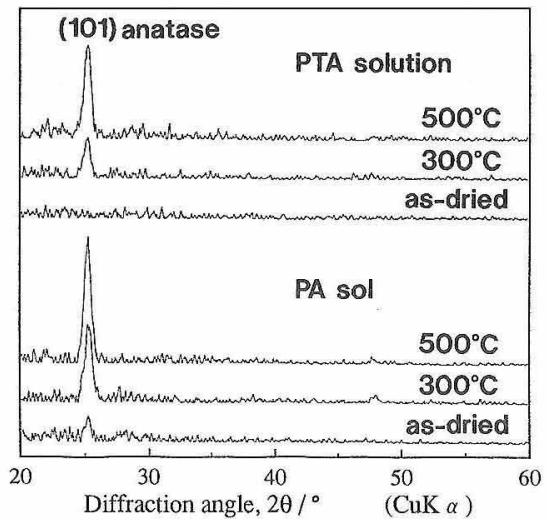

Fig. 1. XRD profiles of films prepared from PTA solution and PA sol onto glass substrate.

tained from PTA solution crystallize to the anatase phase above $300^{\circ} \mathrm{C}$, while the films obtained from PA sol crystallize before the heat treatment. The peak intensity of the (101) plane increases with increasing heating temperature up to $500^{\circ} \mathrm{C}$, and no other peaks are observed, indicating the preferred (101) orientation.

Figures 2 and 3 show SEM micrographs of a cross section and the surface of the films prepared from PTA solution and PA sol. Fine particles below $100 \mathrm{~nm}$ in diameter are observed clearly in the as-dried PA film and its surface seems to be rough. Particles over $100 \mathrm{~nm}$ in diameter are considered to be aggregates of fine particles. In contrast, in the as-dried PTA film, it is difficult to observe particles by SEM, and the film surface is very smooth. In the case of the film heated at $300^{\circ} \mathrm{C}$, the morphology of PA film is the same as that of the as-dried film. Fine particles are seen in the cross section of PTA film, but the film surface remains smooth. At $500^{\circ} \mathrm{C}$, all films are observed to be dense.
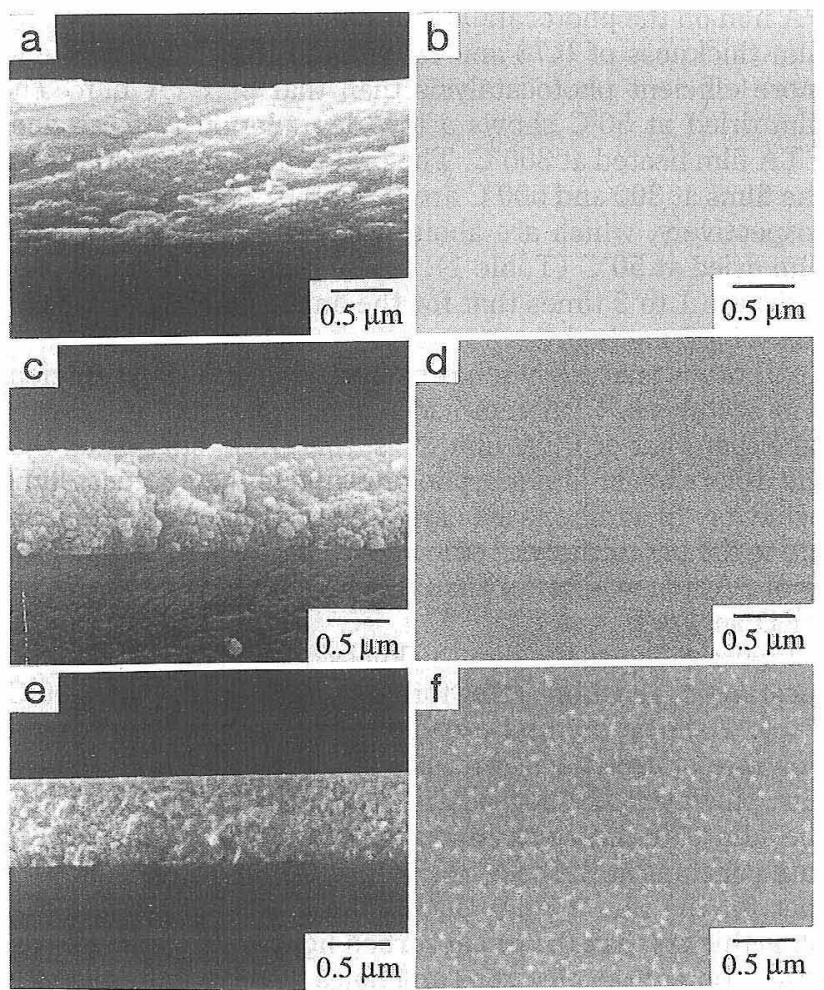

Fig. 2. SEM micrographs of cross section and surface of PTA films heated at $(\mathrm{a}, \mathrm{b}) 50^{\circ} \mathrm{C},(\mathrm{c}, \mathrm{d}) 300^{\circ} \mathrm{C}$ and $(\mathrm{e}, \mathrm{f}) 500^{\circ} \mathrm{C}$.
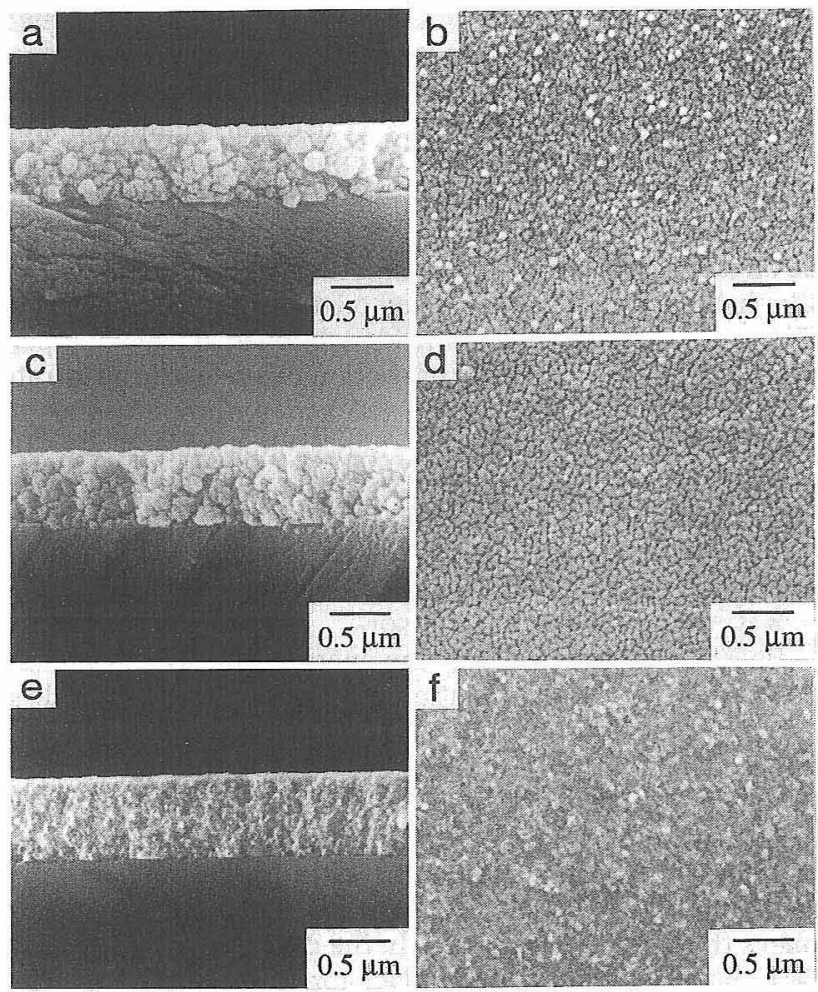

Fig. 3. SEM micrographs of cross section and surface of $P A$ films heated at $(\mathrm{a}, \mathrm{b}) 50^{\circ} \mathrm{C},(\mathrm{c}, \mathrm{d}) 300^{\circ} \mathrm{C}$ and $(\mathrm{e}, \mathrm{f}) 500^{\circ} \mathrm{C}$.

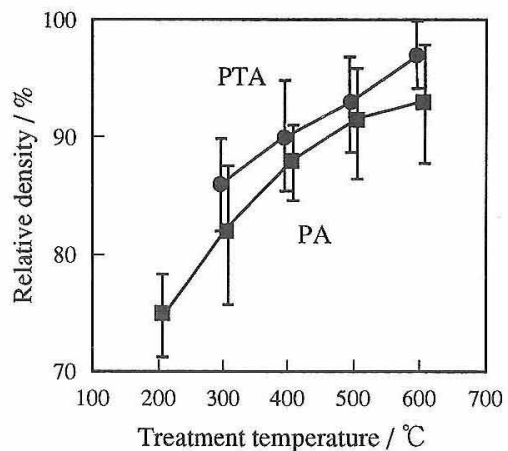

Fig. 4. Relative densities of anatase films prepared from PTA solution and PA sol.

Figure 4 shows the effect of treatment temperature on relative density of the film: The relative density of the films heated at $300^{\circ} \mathrm{C}$ is above $80 \%$, and that of films heated at $500^{\circ} \mathrm{C}$ is above $90 \%$. The density of PTA films are higher than that of PA films. The density of the films in the present study is high compared with the film prepared by the ordinary sol-gel method.13) Organic compounds in sol prepared by the sol-gel method decompose during the heat treatment and hinder aligned grain growth and densification. ${ }^{14)}$ Since PTA solution and PA sol do not contain any organic compounds, ${ }^{10)}$ the densification of the films occurs at low temperatures. On the other hand, the films in this study crystallized with preferred (101) orientation. Therefore, the structural relaxation of the film, which contributes to the densification and the preferred orientation, may occur during drying and heating. ${ }^{14)}$ Furthermore, since the peroxo group decomposes below $300^{\circ} \mathrm{C},{ }^{10)}$ the films heated at above $300^{\circ} \mathrm{C}$ tend to become denser.

\subsection{Adhesion to substrate}

Adhesion of the film to the substrate, which is one of the 
important characteristics in the actual application, was estimated. No films could be peeled off with cellophane tape.

Figure 5 shows the adhesion of films to substrates estimated by the tensile strength test using an aluminum stud and adhesive. The film thickness was $0.70 \mu \mathrm{m}$. For films heated at $50^{\circ} \mathrm{C}$ and above $300^{\circ} \mathrm{C}$, the adhesive broke off and no part of the film peeled off. Therefore, the actual adhesion strength is greater than the values plotted in Fig. 5. The film heated at $150^{\circ} \mathrm{C}$ was peeled off partially at $15-50 \mathrm{MPa}$. These strong adhesions of the film obtained at a low temperature are due to an interface reaction between the substrate and the film. In other words, the active peroxo groups of PTA and PA react with a certain group, such as the $\mathrm{OH}$ group, on the surface of the substrate during drying and/or heating at a low temperature. The as-dried film no longer redissolves in water. These results indicate that all films have sufficiently high adhesion for actual applications.

3.3 Photocatalytic behavior

Photocatalytic activity of the anatase film was evaluated by measuring the degradation rate of acetic acid which is one of typical ill-smelling compounds. Figure 6 shows the effect of the treatment temperature of the film from PTA solution on the rate of photocatalytic degradation of acetic acid, for film thickness of $0.70 \mu \mathrm{m}$. The logarithmic concentration of the acetic acid decreases in proportion to the irradiation time. Therefore, the photocatalytic reaction rate obeys the first-order kinetics. In the case of the film dried at $50^{\circ} \mathrm{C}$, little degradation took place for $1 \mathrm{~h}$. An unknown component was detected in the acetic acid solution after irradiation for $2 \mathrm{~h}$, and the light-yellow color of the film disappeared. This component was probably derived from acetic acid by a chemical reaction with the peroxo group in the film. ${ }^{15)}$ Table 1 shows first-order rate constants for the

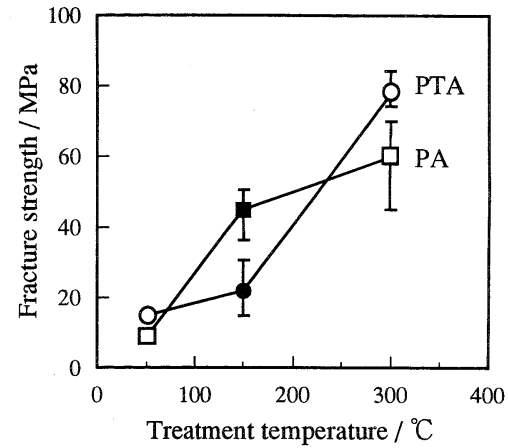

Fig. 5. Adhesion of film to glass substrate estimated by tensile strength test using an aluminum stud and adhesive. and : films peeled off partially. $\bigcirc$ and $\square$ : adhesive broke off but films did not peel off.

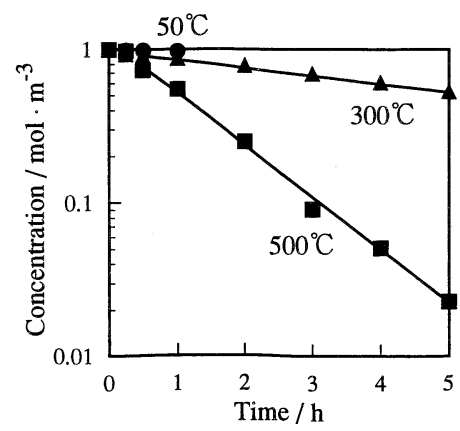

Fig. 6. Effect of heating temperature of PTA film on the rate of photocatalytic degradation of acetic acid. Film thickness was about $0.7 \mu \mathrm{m}$.
Table 1. First-Order Rate Constants for Degradation of Acetic Acid over the Anatase Film

\begin{tabular}{lcc}
\hline Precursor & $\begin{array}{l}\text { Treatment } \\
\text { temperature } /{ }^{\circ} \mathrm{C}\end{array}$ & $\begin{array}{l}\text { First-order rate } \\
\text { constant } / \mathrm{min}^{-1}\end{array}$ \\
\hline PTA solution & 50 & - \\
& 300 & 0.0022 \\
PA sol & 500 & 0.012 \\
& 50 & 0.0036 \\
& 300 & 0.027 \\
& 500 & 0.035 \\
\hline
\end{tabular}

* Results for the catalyst surface area of $1 \mathrm{~cm}^{2}$ and for the acetic acid solution volume of $1 \mathrm{~cm}^{3}$.

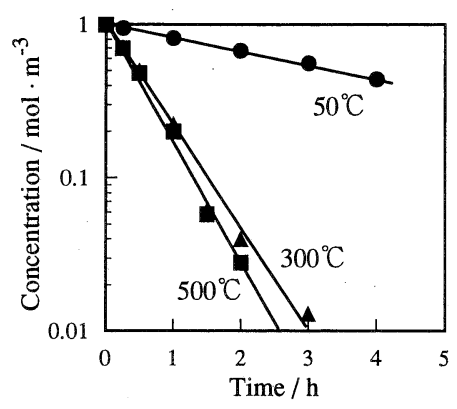

Fig. 7. Effect of heating temperature of PA film on the rate of photocatalytic degradation of acetic acid. Film thickness was about $0.7 \mu \mathrm{m}$.

degradation of acetic acid over the film with a catalyst surface area of $1 \mathrm{~cm}^{2}$ and acetic acid solution volume of $1 \mathrm{~cm}^{3}$. The first-order rate constant for the film heated at $500^{\circ} \mathrm{C}$ is 5.5 times that for the film heated at $300^{\circ} \mathrm{C}$.

Figure 7 shows the effect of the treatment temperature of PA film on the photocatalytic degradation of acetic acid, for film thickness of $0.70 \mu \mathrm{m}$. It is found that PA film shows more efficient photocatalysis than that of PTA film. The film dried at $50^{\circ} \mathrm{C}$ shows a low degradation rate, as does PTA film heated at $300^{\circ} \mathrm{C}$. The first-order rate constants for the films at 300 and $500^{\circ} \mathrm{C}$ are about 0.027 and $0.035 \mathrm{~min}^{-1}$, respectively, which are about 8 and 10 times that for the film dried at $50^{\circ} \mathrm{C}$ (Table 1 ). These photocatalytic reaction rates are 1 to 2 times that for the anatase film prepared by the sol-gel method. ${ }^{3}$ )

A porous anatase film has been reported to show efficient photocatalysis. ${ }^{3)} \mathrm{PA}$ film had more porous and rough surface than that of PTA film. It is, therefore, suggested that the difference in film morphology affects the photocatalytic behavior. In addition, the crystallinity of films may contribute to the photocatalytic efficiency, ${ }^{4}$ because the crystallinity of PA film was better than that of PTA film, according to XRD analysis.

Figure 8 shows the film thickness dependence of the photocatalytic reaction rate for $\mathrm{PA}$ film heated at $300^{\circ} \mathrm{C}$. Table 2 shows the first-order rate constants. The degradation rate of acetic acid with use of the film $0.38 \mu \mathrm{m}$ thick is low. However, the degradation rate constant in the case of the film $0.70 \mu \mathrm{m}$ thick increases by about 2.5 times. The rate constant in the case of the film $1.0 \mu \mathrm{m}$ thick is close to that for the film $0.7 \mu \mathrm{m}$ thick. These results indicate that films thicker than $0.7 \mu \mathrm{m}$ absorbed light well, leading to the generation of the electrons and holes which were efficiently captured by the reactants such as oxygen, water and acetic acid. ${ }^{5)}$ 


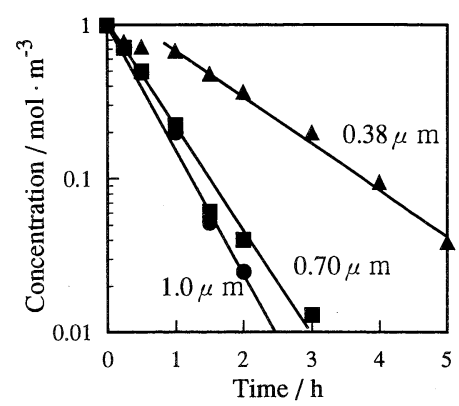

Fig. 8. Film thickness dependence of photocatalytic activity for $\mathrm{PA}$ film heated at $300^{\circ} \mathrm{C}$.

Table 2. Film Thickness Dependence of First-Order Rate Constants for Degradation of Acetic Acid over PA Film Heated at $300^{\circ} \mathrm{C}$

\begin{tabular}{cc}
\hline $\begin{array}{l}\text { Film } \\
\text { thickness } / \mu \mathrm{m}\end{array}$ & $\begin{array}{l}\text { First-order rate } \\
\text { constant / } \mathrm{min}^{-1}\end{array}$ \\
\hline 0.38 & 0.010 \\
0.70 & 0.027 \\
1.0 & 0.036 \\
\hline
\end{tabular}

* Results for the catalyst surface area of $1 \mathrm{~cm}^{2}$ and for the acetic acid solution volume of $1 \mathrm{~cm}^{3}$.

\section{Conclusion}

Anatase films for use as photocatalysts were prepared on borosilicate glass by a dip-coating technique using PTA solution and $\mathrm{PA}$ sol. High-density film with over $80 \%$ relative density was obtained by heating at $300^{\circ} \mathrm{C}$, and even as-dried films exhibited an excellent adhesion to substrate. These results were inferred to be due to a reaction between the substrate and the peroxo group. It was also revealed that PA film exhibited higher photocatalytic efficiency than that of PTA film, because it had a porous and rough surface and good crystallinity. The photocatalytic efficiency of PA film heated at above $300^{\circ} \mathrm{C}$ was comparable to that of the film obtained by the sol-gel method. PA sol and PTA solution were found to be good precursors of photocatalytic anatase film. They are expected to be applied onto substrates of not only glass and ceramics but also metal and plastics.

\section{References}

1) A. Fujishima, K. Honda and S. Kikuchi, Kogyo-Kagaku Zasshi, 72, 108-13 (1969).

2) K. Hashimoto and A. Fujishima, Shokubai, 36, 524-30 (1994) (in Japanese).

3) K. Kato, A. Tsuzuki, Y. Torii, H. Taoda, T. Kato and Y. Butsugan, J. Mater. Sci., 30, 837-41 (1995).

4) K. Kato, A. Tsuzuki, H. Taoda, Y. Torii, T. Kato and Y. Butsugan, J. Mater. Sci., 29, 5911-15 (1994).

5) I. Sopyan, S. Murasawa, K. Hashimoto and A. Fujishima, Chem. Lett., 723-26 (1994).

6) T. Yoko, K. Kamiya and S. Sakka, Denki Kagaku, 54, 28485 (1986).

7) H. Dislich and E. Hussman, Thin Solid Films, 77, 129-39 (1981).

8) K. Kamiya, K. Tanimoto and T. Yoko, J. Mater. Sci. Lett., 5, 402-04 (1986).

9) B. E. Yoldas, J. Mater. Sci., 21, 1087-92 (1986).

10) H. Ichinose, M. Terasaki and H. Katsuki, J. Ceram. Soc. Japan, 104, 715-18 (1996).

11) T. Oyama, Seramikkusu, 25, 548-58 (1990) (in Japanese).

12) H. Ichinose, Y. Nibu, H. Katsuki and M. Nagano, Jpn. J. Appl. Phys., 32, 144-49 (1993).

13) S. Sakka, "The Science of Sol-Gel Method", Agune-shofusha, Tokyo (1988) p. 127 (in Japanese).

14) M. Ohyama, H. Kozuka, T. Yoko and S. Sakka, J. Ceram. Soc. Japan, 104, 296-300 (1996).

15) H. J. Ledon and F. Varescon, Inorg. Chem., 23, 2735-37 (1984). 